\title{
The Communications and Internet Revolution in International Relations
}

\section{Elnur Hasan Mikail, Cavit Emre Aytekin}

Department of Political Sciences and International Relations, Faculty of Economics and Administrative Sciences, Kars Kafkas University, Kars, Turkey

Email: emikail@turansam.org, cavitemreaytekin@gmail.com

How to cite this paper: Mikail, E. H., \& Aytekin, C. E. (2016). The Communications and Internet Revolution in International Relations. Open Journal of Political Science, 6, 345-350.

http://dx.doi.org/10.4236/ojps.2016.64031

Received: August 9, 2016

Accepted: September 4, 2016

Published: September 7, 2016

Copyright $\odot 2016$ by authors and Scientific Research Publishing Inc. This work is licensed under the Creative Commons Attribution International License (CC BY 4.0).

http://creativecommons.org/licenses/by/4.0/

\begin{abstract}
In this study, the main subject is the role of the Communications and Internet Revolution in International Relations. The principal motivation of the author to conduct this essay is the need to develop a conceptual and theoretical examination on communications and internet revolution in International Relations. That need is produced by certain technological and structural developments in human life and their effects on the classical understanding of the international relations. The revolutionary developments in communications and internet technology as significant drivers of globalization process, transformation of the communications and information technology into a core of a new world information economy have come into question as globalization proceeds and with the communications and internet revolution we need to understand why global networking has been grown as it did. The main inquiry in this study is whether the rise of global communications has consequences that fundamentally alter the practice of international relations. In order to provide a comprehensive response, the Communications and Internet revolution, the social network and increasing velocity of information must be analyzed clearly.
\end{abstract}

\section{Keywords}

Communication, Internet Revolution, International Relations

\section{Introduction}

In the conduct of international relations, communications and technological developments have always had a critical role. But today's developments in such areas are even more important and determinant in the conduct of international relations because of their harmony with the globalization phenomenon. In first place, the most important consequence of technological change on global politics today is the change in structure 
of international governance. Governance with all of its inter-subjective meanings can be defined as "rulership" which corresponds a socially constructed body of governance. The rise of global Governance is a consequence of the fundamental shift in traditional state system and international politics. Information and communication technologies in particular have an important impact in the dynamics of international relations. Those transformations in global politics and traditional state system will be examined through drawing the role of technology in international relations, new possibilities and realities brought by the communications and internet revolution, and the progression of the globalization phenomenon.

\section{Technology and the Course of International Relations}

Technology and their effects on daily life has always had influenced international relations and politics. As an important key determinant shaping international relations, communications technology and internet revolution reminds the past developments in technology which has certain effects on international politics and the course of the history such as the industrial revolution which induced the modern international system (Malik, 2012: p. 21). And consequently technological developments and progressions remains to be an instrument of accumulating power for states however the internet, which is the latest technological revolution universal level could bring a change to that tradition with its absolute effects on the course of international politics and the structure of relations between the actors of international relations. In this part of the study the main focus of the article is on the relationship between technological and political change in the context of global politics, focusing on the relationship between the Internet and sovereign territorial states.

Communications and internet technology is also at the core of a new world information economy (Aronson, 2004: p. 2). As a significant driver of globalization communications and developments in internet provided the advent of faster, cheaper communications which is critical to growth, innovation, higher productivity, and job creation. The rise of cheap global communications added new players to the decision-making mix and often forced decisions to be taken more rapidly. National monopolies provided telephone services in almost all countries for decades.

Global communications technology also affects the practice of international relations, making it more difficult for states to keep control. The rise of global communications raised the loss of control of governments over traditional foreign and economic policy issues. That relationship between technology and current international relations is caused by some revolutionary developments in communications and internet technology such as the Rise of data and data transmission, the rise of the Internet and the Web, because of the change in network organization after the pervasion of internet technology (Aronson, 2004: p. 4-5).

Thus the balance of power among actors in international relations was changed by the communications and internet revolution. The communications and internet revolution already have had tremendous security, political, economic, social and cultural 
consequences. That process has altered roles of countries, companies, non- governmental organizations, international institutions and individuals and then examines the consequences for international relations already evident.

The communications and internet revolution has also a determinant of the government's role such as bringing a new responsibility to policymakers to have access to much more information. Therefore rise of global communications means that decision-making bodies of a state have to follow and react the flow of information, because the usage of internet along with the age of globalization governments, is not the monopoly of information any more. Firms, journalists, and Non-governmental organizations can produce and access information as much as governments. And that development provides transparency to everybody, making it difficult for countries unilaterally to take national policy decisions when the problems are global. As globalization is empowering and increasing the numbers of Non-Governmental.

Organizations the Non-governmental organizations can also create information and organize people and groups.

However according to some scholars as a consequence of the effects induced by the communications and internet revolution on international relations, international institutions become both more important and less effective international actors because of the rise of global networks. They are more important because in the absence of effective national policies to deal with globalization, these institutions are the logical venues through which to organize co-operative international policies. They are less effective because critics of such institutions, who complain that they are neither democratic nor even-handed, have stymied their initiatives at major junctures (Aronson, 2004: p. 11). These kinds of shifts influenced world politics and the theory of international relations. Global communications enabled and empowered new nongovernmental institutions and accelerated and broadened transnational contacts between states and non-state actors in other countries.

The communications and internet revolution also changed the methods of intelligence. However, access to more information does not automatically translate into better policy decisions or greater national security. Components of this change includes: intelligence gathering and its impact on foreign policy; the rise of cyber terrorism (Weimann, 2005: p. 135). Because cyber terrorists trying to use information technology to further their aims (Weimann, 2005: p. 135). Thus, figuring out what intelligence matters becomes imperative in the conduct of electronic espionage, especially because cyber terrorists have access to almost the same information on the Web.

Communications and internet revolution allow governments to try to use "soft power" to influence the views of others through television, radio, and print media and via the Web (Nye, 2002: p. 67). Those who generate the information view it at "public diplomacy". Those on the receiving end are more likely to see such broadcasts as propaganda.

New communications and information technologies empower Non-governmental organizations, firms, revolutionaries, terrorists, fundamentalist religious leaders, ex- 
tremists of all stripes, criminal syndicates, and political oppositions as well as social movements, reformers and activists.

\section{The Effects on International Relations}

International relations have always been profoundly affected by technology. The Internet as the latest technological revolution in universal level has such a profound impact. It constitutes, new communications possibilities new trade systems and provides people's ability to communicate globally. Just as ocean-going sailing ships enabled the expansion of Europe in the 16th - 18th centuries, the telegraph underpinned the empires of the 19th century and the aeroplane, radio and TV have transformed international relations in the 20th century (Fahim, 2010: p. 90), the Internet creates a new set of opportunities and risks for the world. The main difference is that the changes will happen faster.

The classical theories of International relations are hardly adapted to the role of technological developments as opposite to its determinant role in the course of the history. Although the phenomenon of globalization did not eradicate the state-centric relations together with the technological developments it brought a complexity to international relations. So the communications and international relations must be studies carefully and more comprehensive than being considered just as a new type of threat to security. The communications and internet revolution is also raises new opportunities and challenges that will change the way that the existing structure works.

The nature of communications and internet revolution has impacts on states and individuals, the content that flows over global networks, the communication infrastructure, and the global regulatory environment. So the advent of global networks will transform international relations as much as the end of the Cold War. The communications and internet revolution could alter the traditional hierarchical bureaucratic organizations order which is also a product of previous technological revolutions, such as industrial revolution. In civil societies, as decentralized organizations and virtual communities develop on the Internet, they cut across territorial jurisdictions and develop their own patterns of governance.

The structure of international system is still based on sovereign statessince the Peace of Westphalia in 1648 (Snyman-Ferreira, 2006: p. 10). However there are newly-emerging realities related with the structure of that sovereignty-based state system. As an outstanding instance, the globalization and internet revolution as driving force of that phenomenon is changing the traditional understanding and role of sovereignty in international relations. The issue of sovereignty is hotly contested in international relations today. The sovereignty and state-centrism resists anything that seems to diminish the current world order. The constituting impacts and apparatus of states such as a source of political identity, ethnic group, religion and nationality faces a cosmopolitan challenge of globalization with the aid of internet revolution and global communications people starts to see cosmopolitan identities such as "global citizen" or "custodian of planet Earth (Tomlinson. 2003: p. 269). Since identities such as nationalism are not 
directly experienced, they are "imagined communities" that depend very much on the effects of communication. As another effect on international relations, as globalization proceeds, the global governance which can be considered as an important outcome of communications and internet revolution becomes more visible. For those reasons of eradicating the very bases of state system, governments react to new developments and consequences of globalization phenomenon and the internet revolution which strengthens the dynamics of globalization (Aronson, 2004: p. 20).

There is considerable debate about the impact of globalization on risk and uncertainty, growth and inequality, democracy and freedom, family and social relationships, and international affairs. But globalization is a dynamic process that governments and other actors continuously influence. The communications and internet revolution caught policy-makers unprepared but, as it continues to unfold, the choices that governments (and other actors) make about policy do matter. So far governments and international institutions have advanced no coherent plan about how or even whether they should guide the communications and internet revolution or about how to create an international regime for cyberspace.

\section{Conclusion}

The Westphalian international system is being challenged by communications and internet revolution. The absolutes of the Westphalian system were territorially fixed states with a single secular authority governing each territory and representing it outside its borders. And in Westphalian understanding which is the fundamental of modern international system and ways of state behavior in bilateral relations and also in international system was based on no high authority principle. But those are dissolving in the process of globalization and the effects on communications and internet revolution.

To sum up: as in the past, so in the future, technology will have a great role in shaping the course of international relations. And like the classical understandings of state system, the geopolitical and strategic choices of the states would change and have new instruments. The technological development and internet revolution could construct a new structure for alliances and behaviors of states. In a globalized world economy, countries will take advantage of their comparative technological advantage over others. Access to technology and control the information will be a determinative factor of power concept.

\section{References}

Aronson, J. D. (2004). The Causes and Consequences of the Global Communication Revolution. In J. Baylis, \& S. Smith (Eds.), The Globalization of World Politics (3rd Edition, pp. 621-643). Oxford: Oxford University Press.

Fahim, M. Y. (2010). Diplomacy, the Only Legitimate Way of Conducting International Relations.

Malik, M. (2012). Technopolitics: How Technology Shapes Relations Among Nations. The Interface of Science, Technology \& Security, 12, 21-29.

http://apcss.org/wp-content/uploads/2012/12/Mohan-Malik.pdf 
Nye, J. S. (2002). The Information Revolution and American Soft Power. Asia-Pacific Review, 9, 60-76. http://dx.doi.org/10.1080/13439000220141596

Snyman-Ferreira, M. P. (2006). The Evolution of State Sovereignty: A Historical Overview. Fundamina, 12, 1-28.

Tomlinson, J. (2003). Globalization and Cultural Identity. In D. Held (Ed.), The Global Transformations Reader: An Introduction to the Globalization Debate (pp. 269-277). Cambridge, UK: Polity.

Weimann, G. (2005). Cyberterrorism: The Sum of All Fears? Studies in Conflict \& Terrorism, 28, 129-149. http://dx.doi.org/10.1080/10576100590905110

Submit or recommend next manuscript to SCIRP and we will provide best service for you:

Accepting pre-submission inquiries through Email, Facebook, LinkedIn, Twitter, etc. A wide selection of journals (inclusive of 9 subjects, more than 200 journals)

Providing 24-hour high-quality service

User-friendly online submission system

Fair and swift peer-review system

Efficient typesetting and proofreading procedure

Display of the result of downloads and visits, as well as the number of cited articles

Maximum dissemination of your research work

Submit your manuscript at: http://papersubmission.scirp.org/ 